\title{
Synthesis of Mono- and Dinuclear Cyclometallated Compounds with Palladium and Platinum ${ }^{+}$
}

\author{
Marcos Rúa-Sueiro*, Paula Munín-Cruz, Francisco Reigosa, José M. Vila M. Teresa Pereira \\ and Juan M. Ortigueira \\ Department of Inorganic Chemistry, Faculty of Chemistry, University of Santiago de Compostela, \\ Avda. das Ciencias s/n, 15782 Santiago de Compostela, Spain \\ * Correspondence: marcos.rua.sueiro@usc.es \\ + Presented at the 24th International Electronic Conference on Synthetic Organic Chemistry, \\ 15 November-15 December 2020; Available online: https:/ecsoc-24.sciforum.net/.
}

Received: date; Accepted: date; Published: date

\begin{abstract}
Cyclometallated compounds, particularly with palladium and platinum, have been extensively studied over the past years in part due to their applications as catalysts in cross-coupling reactions. They are also useful in medicinal chemistry, and quite a large number have luminescent properties. Herein, the synthesis and characterization of novel palladium cyclometallated compounds and a study of their reactivity with a diphosphine ligand is discussed. Mono- and dinuclear compounds were prepared depending on phosphine ligand coordination. Characterization has been carried by IR spectroscopy, ${ }^{1} \mathrm{H}$ and ${ }^{31} \mathrm{P}$ NMR spectroscopy
\end{abstract}

Keywords: cyclometallation; palladium; platinum; thiosemicarbazone; diphosphine

\section{Introduction}

Applications like anticancer agents [1-4] always make cyclometallated compounds a very interesting kind of complexes to study. In addition, these structures containing transition metals such as palladium $[5,6]$ or platinum $[7,8]$ make then even more interesting, comparing their activity to cis-platin.

The ligands used in this research work, thiosemicarbazones, have also been studied in biological assays, Refs. [9-12] making them a good choice for synthesizing cyclometallated compounds with different metal centers.

Other important property of these compounds is their catalytic activity [13-15]. This is very important in chemical and pharmaceutical industry, being used as catalysts in a lot of reactions.

The coordination of the metal center, depending on the ligands used to synthesize the cyclometallated compounds is really important, creating different kind of structures that could be studied in cross-coupling reactions like Suzuki or Heck [16-18].

\section{Experimental}

\subsection{Cyclometallated Compounds}

$\mathrm{K}_{2} \mathrm{PdCl}_{4}$ or $\mathrm{K}_{2} \mathrm{PtCl}_{4}$ were added in $6 \mathrm{~cm}^{3}$ of water. After total solubilization, the corresponding thiosemicarbazone ligand was added in ethanol $\left(25 \mathrm{~cm}^{3}\right)$. The mixture was stirred at room temperature for $24 \mathrm{~h}$. A suspension formed, that was centrifugated and the solid was dried under vacuum. 


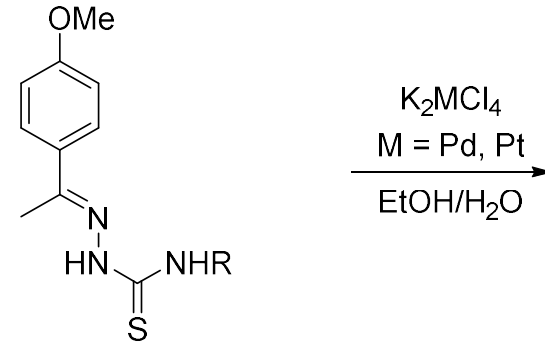

$\mathrm{R}=\mathrm{H}, \mathrm{Me}, \mathrm{Et}$

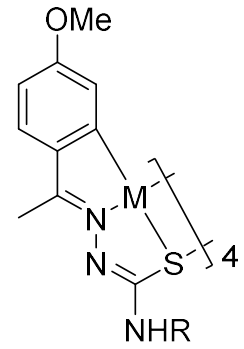

$M=P d 1 a-3 a$

$M=P t 4 a-6 a$

Scheme 1. Reaction sequence leading to the synthesis of cyclometallated compounds.

Table 1. Quantities of reagents used.

\begin{tabular}{cccccc}
\hline Compound & $\mathbf{R}$ & $\mathbf{M}$ & $\left.\mathbf{K}_{2} \mathbf{M C l}_{\mathbf{4}} \mathbf{( m g}\right)$ & Thiosemicarbazone (mg) & Efficiency (\%) \\
\hline $1 \mathrm{a}$ & $\mathrm{H}$ & $\mathrm{Pd}$ & 200 & 164 & 71 \\
$2 \mathrm{a}$ & $\mathrm{Me}$ & $\mathrm{Pd}$ & 200 & 174 & 78 \\
$3 \mathrm{a}$ & $\mathrm{Et}$ & $\mathrm{Pd}$ & 200 & 185 & 86 \\
$4 \mathrm{a}$ & $\mathrm{H}$ & $\mathrm{Pt}$ & 150 & 80,7 & 85 \\
$5 \mathrm{a}$ & $\mathrm{Me}$ & $\mathrm{Pt}$ & 150 & 85,8 & 85 \\
$6 \mathrm{a}$ & $\mathrm{Et}$ & $\mathrm{Pt}$ & 150 & 90,8 & 86 \\
\hline
\end{tabular}

\subsection{Reaction with Diphosphine}

The cyclometallated compound and the corresponding amount of dppm were added under nitrogen in $15 \mathrm{~cm}^{3}$ of deoxygenated acetone. After stirring at $50{ }^{\circ} \mathrm{C}$ for $24 \mathrm{~h}$, a solid was obtained, and was centrifugated and dried under vacuum.

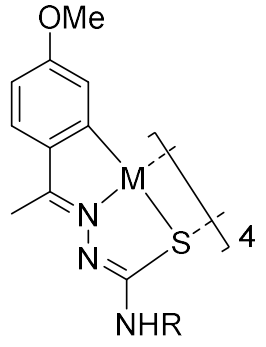

$M=P d 1 a-3 a$

$M=P t 4 a-6 a$
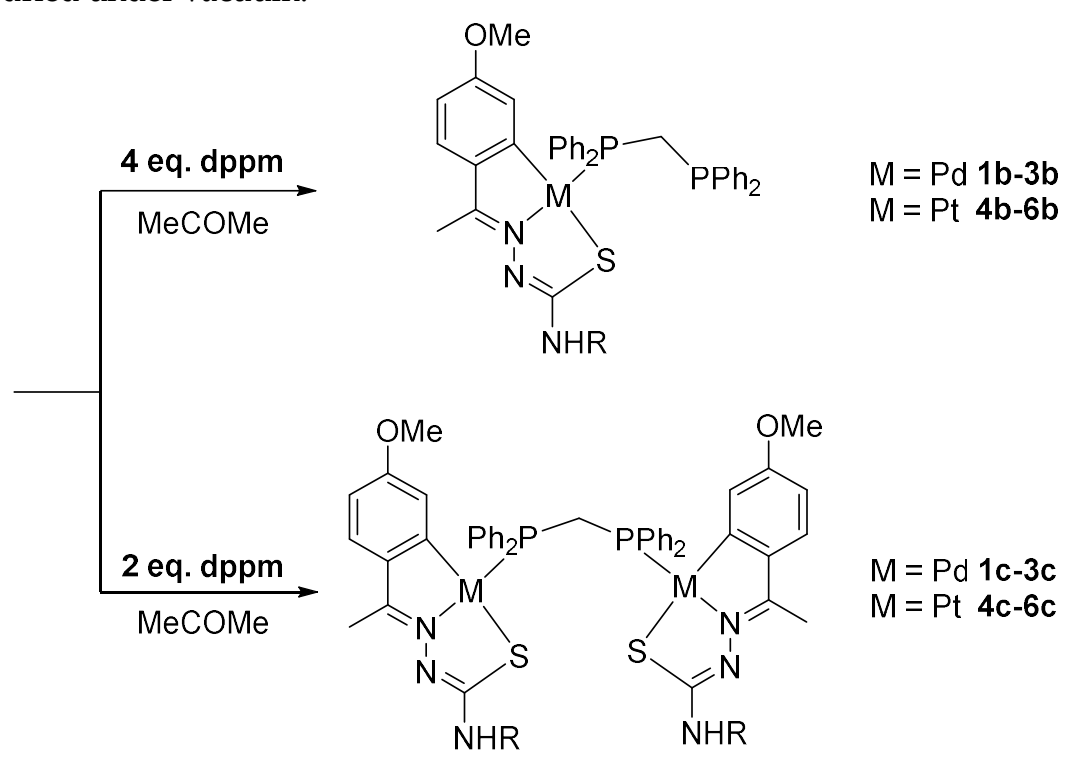

Scheme 2. Synthesis of mono- and dinuclear structures with dppm.

Table 2. Quantities of reagents used.

\begin{tabular}{ccccccc}
\hline Compound & R & M & dppm (eq.) & Metallacycle (mg) & dppm (mg) & Efficiency (\%) \\
\hline 1b & H & Pd & 4 & 35 & 41,0 & 60 \\
2b & Me & Pd & 4 & 35 & 39,3 & 75 \\
3b & Et & $\mathrm{Pd}$ & 4 & 35 & 37,8 & 72 \\
4b & H & $\mathrm{Pt}$ & 4 & 35 & 32,3 & 64 \\
\hline
\end{tabular}




\begin{tabular}{ccccccc}
\hline $5 \mathrm{~b}$ & $\mathrm{Me}$ & $\mathrm{Pt}$ & 4 & 35 & 31,3 & 59 \\
$6 \mathrm{~b}$ & $\mathrm{Et}$ & $\mathrm{Pt}$ & 4 & 35 & 30,2 & 61 \\
$1 \mathrm{c}$ & $\mathrm{H}$ & $\mathrm{Pd}$ & 2 & 35 & 20,5 & 56 \\
$2 \mathrm{c}$ & $\mathrm{Me}$ & $\mathrm{Pd}$ & 2 & 35 & 19,7 & 64 \\
$3 \mathrm{c}$ & $\mathrm{Et}$ & $\mathrm{Pd}$ & 2 & 35 & 18,9 & 64 \\
$4 \mathrm{c}$ & $\mathrm{H}$ & $\mathrm{Pt}$ & 2 & 35 & 16,2 & 60 \\
$5 \mathrm{c}$ & $\mathrm{Me}$ & $\mathrm{Pt}$ & 2 & 35 & 15,6 & 61 \\
$6 \mathrm{c}$ & $\mathrm{Et}$ & $\mathrm{Pt}$ & 2 & 35 & 15,1 & 66 \\
\hline
\end{tabular}

\section{Results and Discussion}

All compounds synthesized were characterized by IR spectroscopy, ${ }^{1} \mathrm{H}$ and ${ }^{31} \mathrm{P}$ NMR spectroscopy.

\subsection{IR Spectroscopy}

The IR spectra (Table 3) shows that the $v\left(\mathrm{~N}_{\text {hydrazinic }}-\mathrm{H}\right)$ and $v(\mathrm{C}=\mathrm{S})$ stretches are absent in the cyclometallated compounds, compared to the ligand. These confirm that the deprotonation of the Hhydrazinic and the loss of $\mathrm{C}=\mathrm{S}$ double bond character is needed for the formation of the palladacycle.

Table 3. Stretch bands data.

\begin{tabular}{ccccc}
\hline Compound & $\mathbf{R}$ & $\mathbf{M}$ & $\boldsymbol{v}($ Nhydrazinic-H $)$ & $v(\mathbf{C}=\mathbf{S})$ \\
\hline 1a & $\mathrm{H}$ & $\mathrm{Pd}$ & $3159 / 3292$ & - \\
2a & $\mathrm{Me}$ & $\mathrm{Pd}$ & 3353 & - \\
3a & $\mathrm{Et}$ & $\mathrm{Pd}$ & 3341 & - \\
4a & $\mathrm{H}$ & $\mathrm{Pt}$ & $3215 / 3320$ & - \\
5a & $\mathrm{Me}$ & $\mathrm{Pt}$ & 3286 & - \\
6a & $\mathrm{Et}$ & $\mathrm{Pt}$ & 3303 & - \\
\hline
\end{tabular}

\subsection{H NMR Spectroscopy}

The disappearance of the ortho aromatic proton resonance and the hydrazinic proton resonance ensures cyclometallation.

The aromatic signals change their multiplicity and the signals appear upfield compared to the ligand due to the coordination of the metal center.

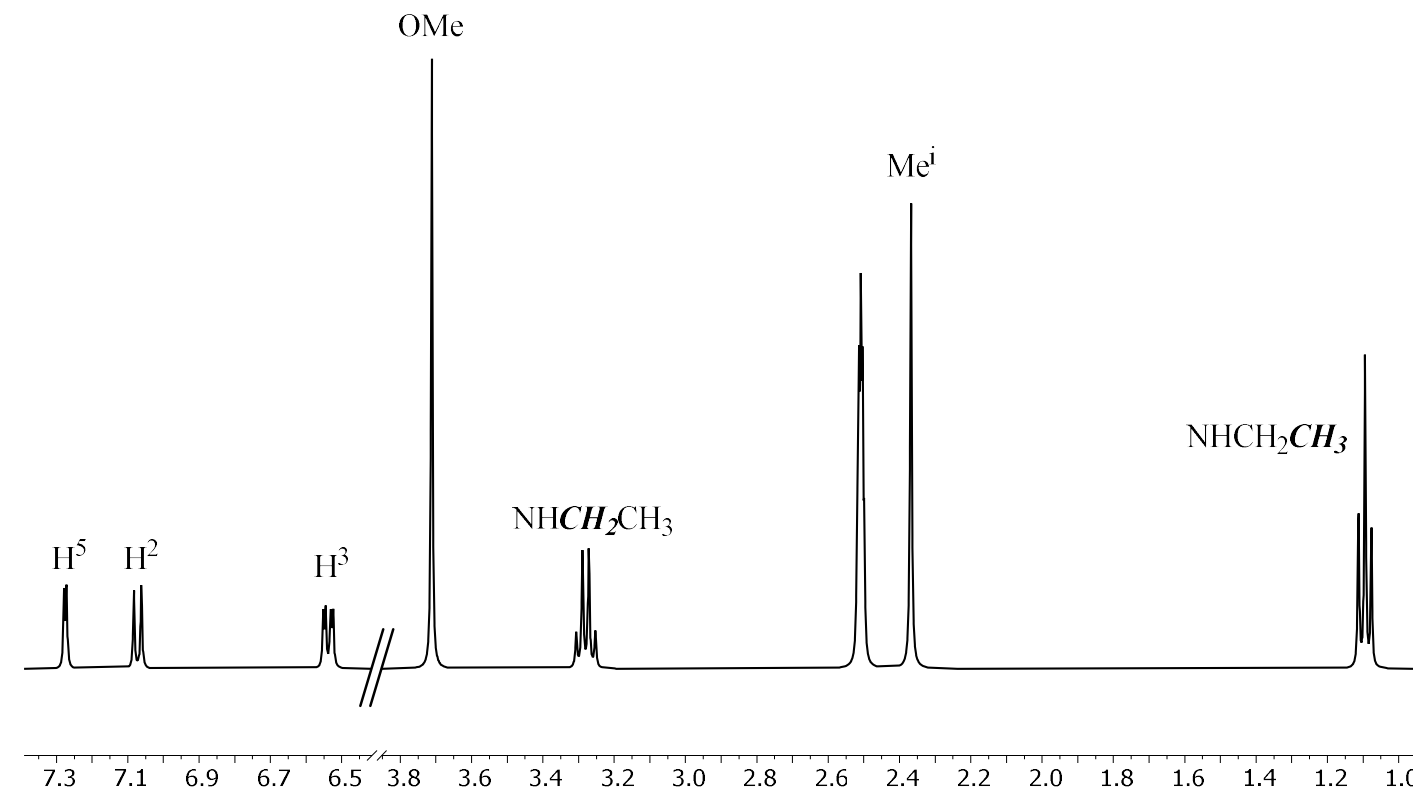


Figure 1. ${ }^{1} \mathrm{H}$ NMR spectrum of compound 6a in DMSO-d6.

In both reactions with the phosphine ligand, the spectrums show two differences with the tetranuclear ones. First, the appearance of the signals related to the diphosphine $\left(\mathrm{Ph}_{2} \mathrm{PCH}_{2} \mathrm{PPh}_{2}\right)$. In addition, the proton $\mathrm{H}^{5}$ appears upfield, because of the effect caused by the phenyl rings of the diphosphine, producing a strong shielding in that position.

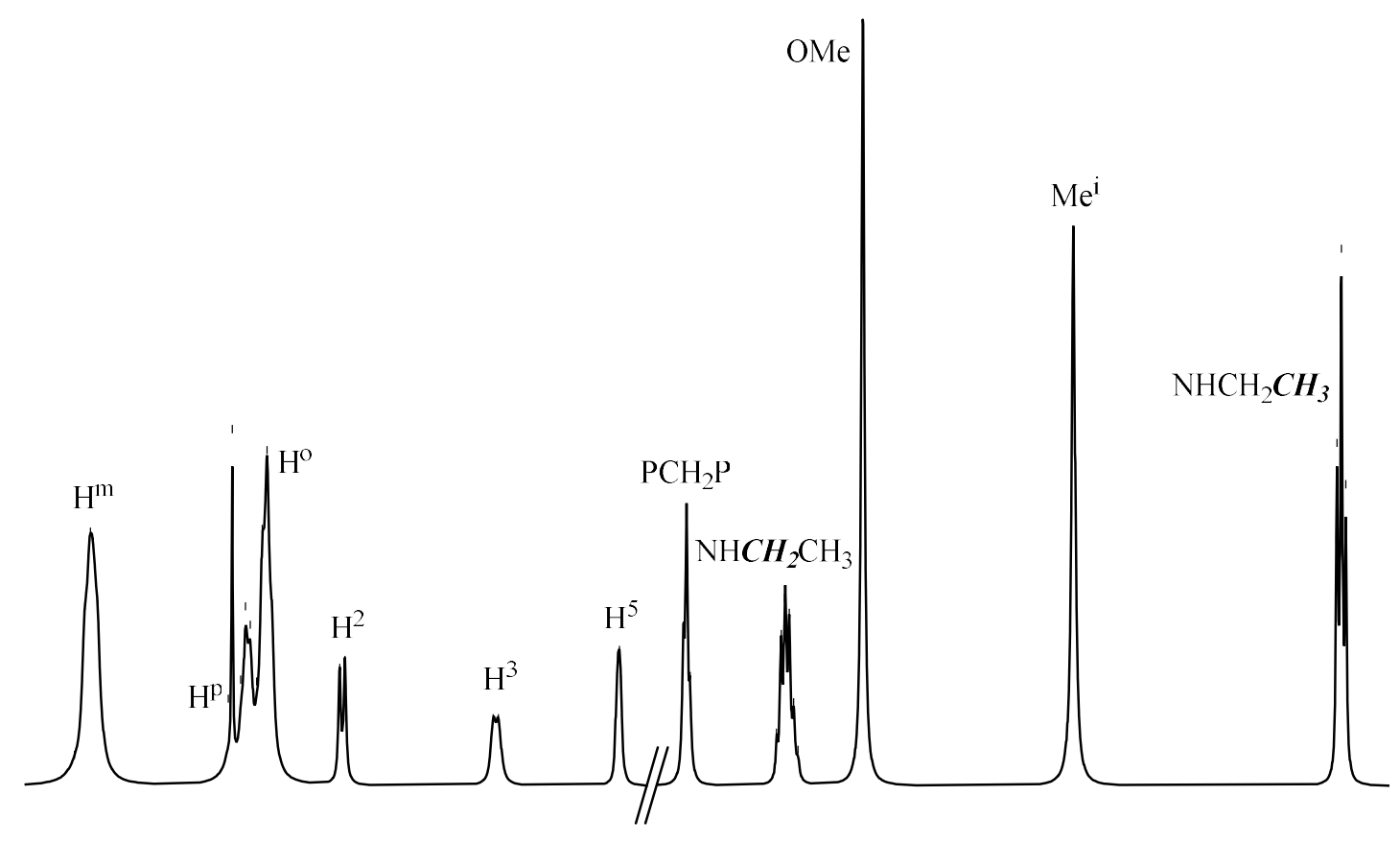

$\begin{array}{llllllllllllllllllllllllllllllll}8.0 & 7.8 & 7.6 & 7.4 & 7.2 & 7.0 & 6.8 & 6.6 & 6.4 & 6.2 & 6.0 & 5.8 & 5.6 & 3.8 & 3.6 & 3.4 & 3.2 & 3.0 & 2.8 & 2.6 & 2.4 & 2.2 & 2.0 & 1.8 & 1.6 & 1.4 & 1.2\end{array}$

Figure 2. ${ }^{1} \mathrm{H}$ NMR spectrum of compound $3 \mathrm{c}$ in $\mathrm{CDCl}_{3}$

\subsection{P NMR Spectroscopy}

${ }^{31} \mathrm{P}$ NMR spectrum gives a lot of information about the structure in solution. Depending on the coordination of the diphosphine ligand with the tetranuclear structure the signals will differ considerably, as shown in Scheme 3.

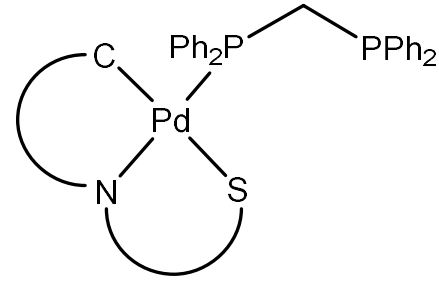

Monodentade

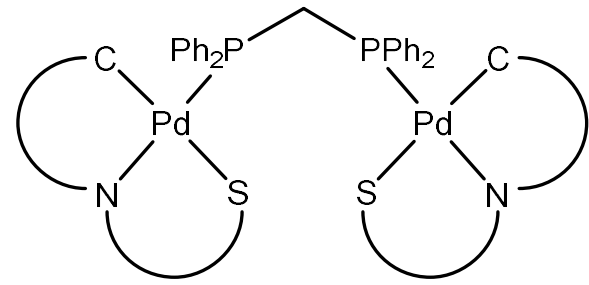

Brigding bidentade

Scheme 3. Possible behavior of the phosphine ligand.

In these compounds the diphosphine could act as a monodentate ligand or as a brigding bidentate one.

For the first reaction, the ${ }^{31} \mathrm{P}$ NMR spectrum shows two doublets, one for each phosphorus, due to the coordination of one of them $\left({ }^{2} \mathrm{JP}\right.$ coordinated $\left.\mathrm{P}_{\text {free }}=79.7 \mathrm{~Hz}\right)$. This agrees with the stoichiometry used in this reaction, with four equivalents of dppm. In addition, in Figure 3 appears satellites relative to 
the coupling between ${ }^{195} \mathrm{Pt}$ nucleus and both phosphorus atoms $\left({ }^{1} \mathrm{JPtP}\right.$ coordinated $=3835.2 \mathrm{~Hz}$ and ${ }_{3} \mathrm{JPtP}$ free $=66.6 \mathrm{~Hz}$ ).

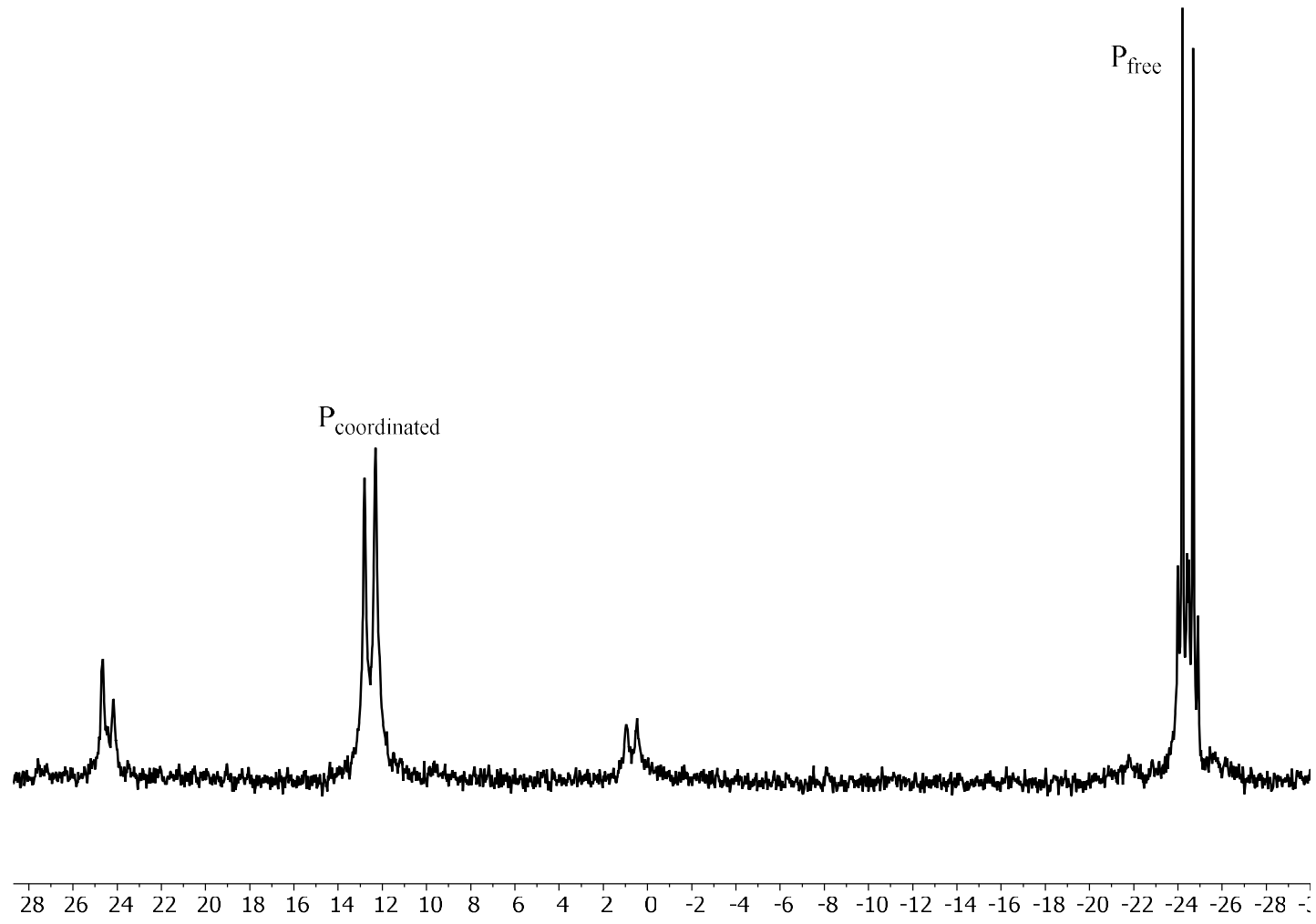

Figure 3. ${ }^{31} \mathrm{P}-\left\{{ }^{1} \mathrm{H}\right\}$ NMR of compound $5 \mathrm{~b}$ in acetone- $\mathrm{d}_{6}$.

For the second reaction, the spectrum shows only one signal (Figure 4). This agrees with the structure proposed, because the two phosphorus are coordinated to a metal center and they are equivalent. 


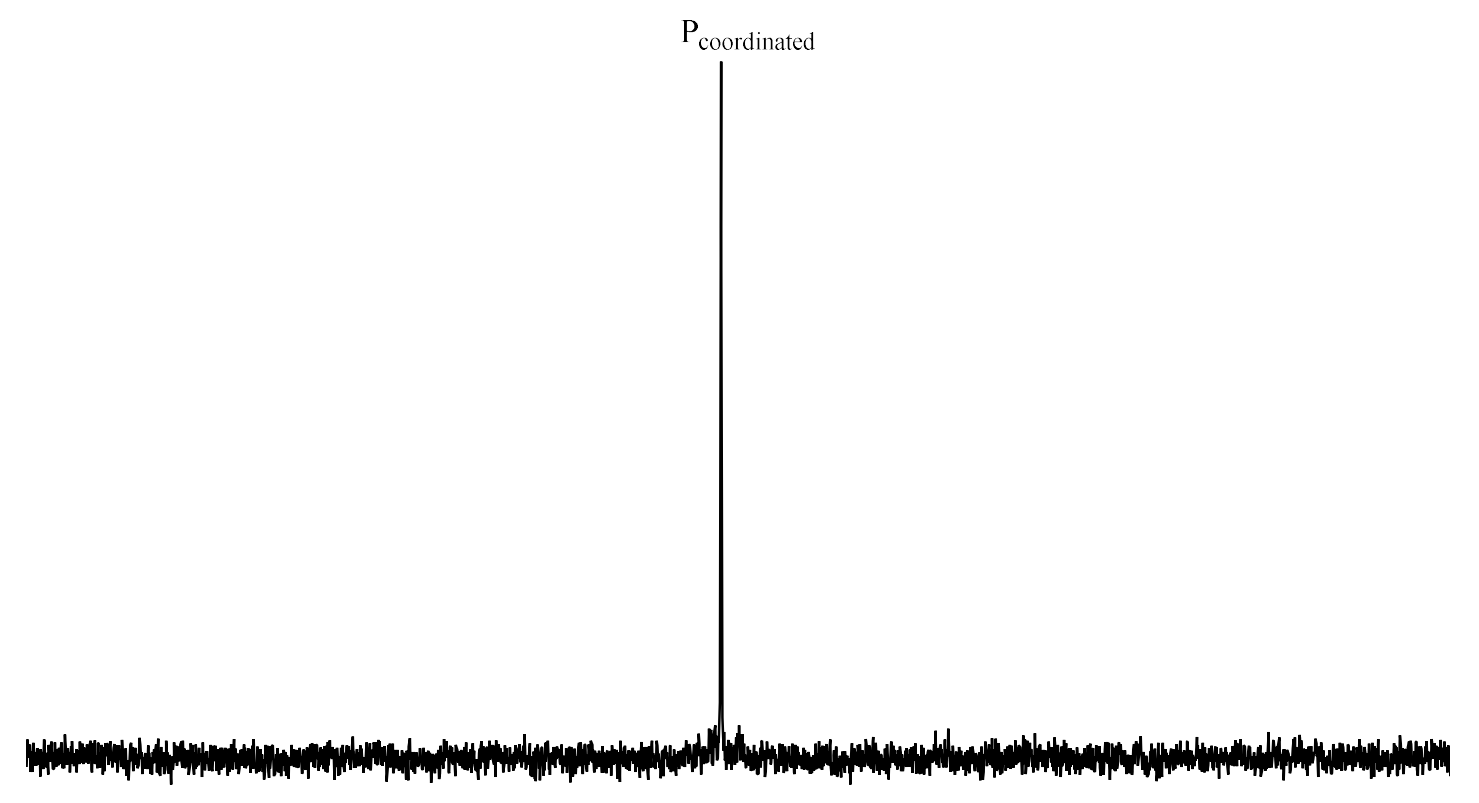

$\begin{array}{llllllllllllllllllllllllllll}85 & 80 & 75 & 70 & 65 & 60 & 55 & 50 & 45 & 40 & 35 & 30 & 25 & 20 & 15 & 10 & 5 & 0 & -5 & -10 & -15 & -20 & -25 & -30 & -35 & -40\end{array}$

Figure 4. ${ }^{31} \mathrm{P}-\{1 \mathrm{H}\}$ NMR spectrum of compound $3 \mathrm{c}$ in $\mathrm{CDCl}_{3}$.

\section{Conclusions}

Coordination to the metal center occurs in the thiol form of the thiosemicarbazone, approved by IR spectroscopy.

${ }^{1} \mathrm{H}$ NMR spectroscopy confirms cyclometallation, with the thiosemicarbazone ligand as tridentate $[\mathrm{C}, \mathrm{N}, \mathrm{S}]$.

The cyclometallated compounds show a tetranuclear structure, with two type of bonds between palladium and sulfur: Pd-Schelate and Pd-Sbridging.

Reaction with dppm 4:1 mixture generates mononuclear compounds with one phosphorus atom free.

Reaction with dppm 2:1 mixture generates dinuclear compounds with the ligand showing a brigding bidentate character.

Funding: F.R. wants to thank the financial support to the Spanish Government (AEI) through an FPU grant (number 13/05014).

Acknowledgments: The authors thank funding from Xunta de Galicia (Galicia, Spain) under the Grupos de Referencia program (GRC 2019/014)

Conflicts of Interest: The authors declare no conflict of interest.

\section{References}

1. Spreckelmeyer, S.; van der Zee, M.; Bertrand, B.; Bodio, E.; Stürup, S.; Casini, A. Front. Chem. 2018, 6.

2. Licona, C.; Delhorme, J.-B.; Riegel, G.; Vidimar, V.; Cerón-Camacho, R.; Boff, B.; Venkatasamy, A.; Tomasetto, C.; Gomes, P. d. S. F. C.; Rognan, D. Inorg. Chem. Front. 2020, 7, 678.

3. Blanckenberg, A.; Van Niekerk, A.; Mapolie, S.F.; Prince, S.; University of Stellenbosch, S. Afr.; University of Cape Town. 2019; 53pp.

4. Frik, M.; Fernández-Gallardo, J.; Gonzalo, O.; Mangas-Sanjuan, V.; González-Alvarez, M.; Serrano del Valle, A.; Hu, C.; González-Alvarez, I.; Bermejo, M.; Marzo, I. J. Med. Chem. 2015, 58, 5825. 
5. Carreira, M.; Calvo-Sanjuán, R.; Sanaú, M.; Marzo, I.; Contel, M. Organometallics 2012, 31, 5772.

6. Fong, T.T.-H.; Lok, C.-N.; Chung, C.Y.-S.; Fung, Y.-M. E.; Chow, P.-K.; Wan, P.-K.; Che, C.-M. Angew. Chem. Int. Ed. 2016, 55, 11935.

7. Ramírez-Rave, S.; Ramírez-Apan, M.T.; Tlahuext, H.; Morales-Morales, D.; Toscano, R.A.; Grévy, J.-M. J. Organomet. Chem. 2016, 814, 16.

8. Oliveira, C.G.; Romero-Canelón, I.; Coverdale, J.P.; Maia, P.I.S.; Clarkson, G.J.; Deflon, V.M.; Sadler, P.J. Dalton Trans. 2020, 49, 9595.

9. King, A.P.; Gellineau, H.A.; Ahn, J.-E.; MacMillan, S.N.; Wilson, J.J. Inorg. Chem. 2017, 56, 6609.

10. Anjum, R.; Palanimuthu, D.; Kalinowski, D.S.; Lewis, W.; Park, K.C.; Kovacevic, Z.; Khan, I.U.; Richardson, D.R. Inorg. Chem. 2019, 58, 13709.

11. Özerkan, D.; Ertik, O.; Kaya, B.; Kuruca, S.E.; Yanardag, R.; Ülküseven, B. Investig. New Drugs 2019, 37, 1187.

12. Yousef, T.A.; Abu El-Reash, G.M. J. Mol. Struct. 2020, 1201, 127180.

13. Ramírez-Rave, S.; Morales-Morales, D.; Grévy, J.-M. Inorg. Chim. Acta 2017, 462, 249.

14. Samiee, S.; Shiralinia, A.; Hoveizi, E.; Gable, R.W. J. Organomet. Chem. 2019, 900, 120927.

15. López-Mosquera, C.; Grabulosa, A.; Rocamora, M.; Font-Bardia, M.; Muller, G. Eur. J. Inorg. Chem. 2020, 2020, 2470.

16. Dharani, S.; Kalaiarasi, G.; Sindhuja, D.; Lynch, V.M.; Shankar, R.; Karvembu, R.; Prabhakaran, R. Inorg. Chem. 2019, 58, 8045.

17. Zhang, D.; Yu, J. Organometallics 2020, 39, 1269.

18. Maji, A.; Singh, O.; Singh, S.; Mohanty, A.; Maji, P.K.; Ghosh, K. Eur. J. Inorg. Chem. 2020, 2020, 1596.

Publisher's Note: MDPI stays neutral with regard to jurisdictional claims in published maps and institutional affiliations.

(C) 2020 by the authors. Submitted for possible open access publication under the terms and conditions of the Creative Commons Attribution (CC BY) license (http://creativecommons.org/licenses/by/4.0/). 